ERRATUM OPEN

\title{
Intravenous delivery of adeno-associated virus 9-encoded IGF-1Ea propeptide improves post-infarct cardiac remodelling
}

Enrique Gallego-Colon, Maria Villalba, Joanne Tonkin, Francisco Cruz, Juan Antonio Bernal, Luis J Jimenez-Borregureo, Michael D Schneider, Enrique Lara-Pezzi and Nadia Rosenthal

npj Regenerative Medicine (2017) 2, 17001; doi:10.1038/npjregenmed.2017.1; published online 20 October 2017

Correction to: npj Regenerative Medicine (2016) 1, 16001; doi:10.1038/npjregenmed.2016.1; published online 9 June 2016

The following statement was missing in the Materials and Methods section: All experiments were approved by the local Ethics Committee at the Centro Nacional de Investigaciones Cardiovasculares (PA5512). The investigation conforms to the principles of Laboratory Animal Care which are formulated by the National Society for Medical Research and the Guide for the Care and Use of Laboratory Animals (US National Institutes of Health Publication 85-23, 1996).

A correction has been published and the statement has now been added in the HTML and PDF versions of this Article.

The erratum published for this paper contained an incorrect ethics statement. The Erratum, and the PDF and HTML versions of the paper, have been updated with the correct ethics statement.

The publication year of the paper stated in the PDF and HTML versions of the paper has also been corrected.

\footnotetext{
(c) (i) This work is licensed under a Creative Commons Attribution 4.0 International License. The images or other third party material in this article are included in the article's Creative Commons license, unless indicated otherwise in the credit line; if the material is not included under the Creative Commons license, users will need to obtain permission from the license holder to reproduce the material. To view a copy of this license, visit http://creativecommons.org/licenses/ by/4.0/
}

(c) The Author(s) 2017 